\title{
A STUDY OF FASTING AND POSTPRANDIAL LIPID ABNORMALITIES IN TYPE 2 DIABETES MELLITUS
}

\author{
Babu $R^{1}$, Shigil Mathew Varghese'2, Seetha Ramireddy $M^{3}$, Arun Kumar $S^{4}$, Ramesh Bala $A^{5}$ \\ ${ }^{1}$ Assistant Professor and Registrar, Department of General Medicine, Vinayaka Missions Medical College and Hospitals, Karaikal. \\ 2Postgraduate Student, Department of General Medicine, Vinayaka Missions Medical College and Hospitals, Karaikal. \\ 3Postgraduate Student, Department of General Medicine, Vinayaka Missions Medical College and Hospitals, Karaikal. \\ ${ }^{4}$ Assistant Professor, Department of General Medicine, Vinayaka Missions Medical College and Hospitals, Karaikal. \\ ${ }_{5}^{5}$ Senior Resident, Department of General Medicine, Vinayaka Missions Medical College and Hospitals, Karaikal.
}

\section{ABSTRACT}

AIM

1. To assess the nature of fasting dyslipidaemia in type 2 diabetes mellitus and correlate the same with severity and duration of diabetes. 2. To assess the postprandial lipid abnormalities in type 2 diabetes and to compare it with that of the fasting lipid load in diabetics.

\section{METHODS}

The study was carried out in Vinayaka Missions Medical College and Hospital, Karaikal over a period of 2 years. A total of 50 patients with type 2 diabetes mellitus were included and were compared with 50 age and sex matched healthy controls fulfilling the inclusion and exclusion criteria.

\section{RESULTS}

In this study, the mean age $\pm S D$ was $48.5 \pm 5.68$ years. The mean $\mathrm{HbA1c} \pm \mathrm{SD}$ was $7.48 \pm 1.517$. All cases in fasting state had raised VLDL-C levels (Mean 50.39 \pm 60.27 ), raised total cholesterol (Mean 169.70 \pm 39.917 ), raised TGL (Mean 146.04 \pm 60.140 ), decreased LDL-C (Mean 92.3 \pm 27.699 ) when compared to control group. In the postprandial state, there was a significant raise in TGL level (Mean 188 \pm 68.59 ), raised total cholesterol (Mean180.74 \pm 38.46 ), decreased HDL-C (Mean 38.761 \pm 9.028 ) compared to the fasting state.

\section{CONCLUSION}

It was found that there was a raised in TGL levels in the postprandial state, raised VLDL-C and reduced LDL-C in fasting state, raised total cholesterol and reduced HDL-C seen in both fasting and postprandial states of diabetic patients.

\section{KEYWORDS}

Dyslipidaemia, Prandial Lipid, VLDL-C Level, Diabetic Patients, and HDL-C.

HOW TO CITE THIS ARTICLE: Babu R, Varghese SM, Ramireddy SM, et al. A study of fasting and postprandial lipid abnormalities in type 2 diabetes mellitus. J. Evolution Med. Dent. Sci. 2016;5(60):4234-4238, DOI: 10.14260/jemds/2016/965

\section{INTRODUCTION}

Diabetes Mellitus (DM) is a metabolic disease in which there is high blood sugar level over a prolonged period. Symptoms include frequent urination (Polyuria), increased thirst (Polydipsia), and increased hunger (Polyphagia). Left untreated long-term complication include CAD, stroke, kidney failure, non-healing ulcer, retinopathy. ${ }^{1}$

Type $2 \mathrm{DM}$ is a chronic disease often considered causing a 10 yrs. shorter life span in affected individuals. It produces a two to four fold increase in the risk of CAD including IHD; 20 fold increase in lower limb amputation; largest cause of nontraumatic blindness, and kidney failure. Atherosclerosis is caused by a combination of diabetes and dyslipidaemia. The major lipid abnormalities seen in DM are elevated Triglyceride (TG) levels and lowered HDL-C levels.

Always most of type 2 diabetics and insulin resistances will be associated with dyslipidaemia like raised TAG and depressed HDL-C level. ${ }^{1}$

Financial or Other, Competing Interest: None.

Submission 10-06-2016, Peer Review 15-07-2016,

Acceptance 21-07-2016, Published 28-07-2016.

Corresponding Author:

Dr. Babu R,

No. 10, Basant Nagar Extension,

Karaikal, Pondicherry,

E-mail: rajivan777@gmail.com

DOI: $10.14260 /$ jemds/2016/965
In nondiabetic individuals, if low density lipids is normal or in a reference range, we supposed to be considerate as low. ${ }^{1}$

Most common cause and risk of coronary artery disease is LDL as per strong heart study demonstrated in American Indians. Best predictor of raised CAD is LDL level (LDL is directly proportional to increasing risk of CAD). Therapy using for lipid abnormalities in diabetic patients. Diabetic having microvascular and macrovascular complications like retinopathy, nephropathy, PVD, CAD, stroke out of some many complications. Atherosclerosis is main cause of mortality in diabetic patient. If DM starts at the same time, individuals risk for myocardial infraction. ${ }^{2}$

Coronary artery disease is having equivalent risk compared to known diabetics. Even Americans Heart Association mentioning that DM is equivalent to CAD. So, always for reducibly the CAD complications, we have to control the lipids and blood pressure. ${ }^{2}$

LDL cholesterol should be below $100 \mathrm{mg} / \mathrm{dL}$ for CAD. Patients or CAD risk patients according for (ATP-III) and NCEP. If HDL less than $40 \mathrm{mg} / \mathrm{dL}$ for men and less than $50 \mathrm{mg} / \mathrm{dL}$ for women with TGL level more than $150 \mathrm{mg} / \mathrm{dL}$ (Both are risks for developing CAD/CHD).3,4 These who are having diabetics or CAD target for LDL-C is less than $100 \mathrm{mg} / \mathrm{dL}$ for DM type 2. Lowering the LDL level, when the same is high, results in decreasing incidence of cardiovascular mortality and morbidity. 
Recent guidance show prophylactic use of statin in $\mathrm{CAD} /$ hypotensive patients with average or lower than average CHO level lowers coronary and stroke whereas raised LDL-CH is atherogenic, a higher HDL-CH level is either itself protective or indicator of a low atherogenic state. ${ }^{5}$

\section{Lifestyle Modification such as}

- Reduced cholesterol diet.

- Reduced fat.

- Regular exercise/retraction of alcohol are the primary approach.

\section{According to NCEP-APE III guidelines (2001)}

1. Those who are $>45$ yrs. (men) and $>55$ yrs. of age.

2. Smoker.

3. Family history of sudden cardiac death.

4. Hypertension (BP - >140/90 mmHg).

5. Diabetic.

6. Low HDL - $\mathrm{CH}<40 \mathrm{mg} / \mathrm{dL}$ in $\mathrm{men}<50 \mathrm{mg} / \mathrm{dL}$ in women.

7. Higher LDL - CH more or less $160 \mathrm{mg} / \mathrm{dL}$ or total more or less $240 \mathrm{mg} / \mathrm{dL}$

8. Obesity - These are the factors risk for coronary artery disease. ${ }^{5}$

9. If LDL is more than $130 \mathrm{mg} / \mathrm{dL}$, there is a chance of high risk in development CAD.

10. If LDL in between $100-129 \mathrm{mg} / \mathrm{dL}$ considered in borderline risk CAD.

11. If LDL is less than 100 consider as low risk individuals.

\section{As well as}

- TGL if more than 400-high risk individual.

- TGL if between 200-399-borderline risk for individual.

- TGL if in less than 200-low risk individual for developing CAD. 6

- Increased TGL level is the main contributor for atherosclerosis CVD in patient with disease.

- So, lowering the level of TGL is the main factor in decreasing cardiovascular mortality (Study done by one ischaemic heart disease-secondary prevention).

- HDL is one playing main role in progressive of CAD. One more study proposal that non-HDL - $\mathrm{CHO}$ will be good indicator for the CAD risk than LDL - CHO - level. ${ }^{7}$

- $\quad$ For type 2 DM patients lipid profile goal for

- Total cholesterol - around less than $170 \mathrm{mg} / \mathrm{dL}$.

- $\quad$ LDL - C - Should be less than $100 \mathrm{mg} / \mathrm{dL}$.

- HDL - C - Should be more than $45 \mathrm{mg} / \mathrm{dL}$.

- $\quad$ TGL - Should be less than $200 \mathrm{mg} / \mathrm{dL}$.

- Non-HDL cholesterol - Should be maintained less than $130 \mathrm{mg} / \mathrm{dL} .^{6}$

\section{METHODOLOGY}

\section{Source of Data}

The study was carried out in, Vinayaka Mission's Medical College and Hospital, Karaikal, over a period of 2 years. A total of 50 patients with type 2 diabetes mellitus were included and were compared with 50 age and sex matched healthy controls fulfilling the inclusion and exclusion criteria.

\section{Inclusion Criteria}

Patients with type 2 diabetes mellitus in between $31-80$ years.

\section{Exclusion Criteria}

- $\quad$ Type 1 diabetes.

- Liver disease.

- $\quad$ Thyroid disorders.

- Nephrotic syndrome.

- Alcoholic.

- Those using medications that affect lipid metabolism such as statins, beta blockers, thiazides, and oral contraceptive pills.

\section{Method of Collection of Data}

Data for the proposed study was collected in a pretested proforma, which included various parameters like age, sex, occupation, religion, income, etc. Detailed history and physical examination of all the cases and controls were done.

Fasting and postprandial lipid levels were estimated in all the cases and controls. Blood was collected from patients after an overnight (12-hour) fast and six hour postprandial (After a standard meal) for lipid profile measurements.

\section{RESULTS}

In the present study, the study group constituted cases from age 31 to 80 years. The majority of cases and controls were in the age group of 41 to 60 years with the mean age of $48.5 \pm 5.68$ years. Male and female were equally distributed in this study. The mean $\mathrm{HbA1C}$ value among the cases was $7.48 \pm 1.517$. There was no correlation between duration of diabetes and dyslipidaemia.

All the cases in the fasting state had a raised VLDL-C (Mean 50.39 \pm 60.27 ), raised total cholesterol (Mean 169.70 \pm 39.917 ), raised TGL (Mean 146.04 \pm 60.140 ), decreased LDL-C (Mean $92.3 \pm 27.699$ ) compared to the control group who had a VLDLC (Mean 32 \pm 22.372 ), total cholesterol (Mean 168.02 \pm 34.65 ), TGL (Mean 138.42 \pm 68.137 ), LDL-C (Mean 105.02 \pm 36.432 ).

In the postprandial state, diabetes patients had a significant raise in TGL levels (Mean 188 \pm 68.59 ), raised in total cholesterol (Mean 180.74 \pm 38.46 ), decreased HDL-C (Mean 38.761 \pm 9.028 ) compared to the fasting state. There was significant increase in TGL, total cholesterol, and reduction in HDL-C in postprandial state compared to the fasting state.

\section{DISCUSSION}

In the present study, fasting and postprandial lipid profile was done in 50 patients with type 2 diabetes mellitus and was compared with the fasting and postprandial lipid profile in 50 healthy controls, age and sex matched, fulfilling the inclusion and exclusion criteria.

\section{Age Distribution of Cases and Controls}

In the present study, the study group constituted cases from age 31 to 80 years. The majority of cases and controls were in the age group of $41-60$ years with a mean age of $57.02 \pm 12.43$ years.

The results are consistent with a similar study done by Sumesh Raj et al $^{8}$ in the year 2005 at Trivandrum, India, wherein the mean age of the cases was $56.6 \pm 11.9$ years and that of the controls was $53.5 \pm 12.7$ years.

In a similar study done by Addisu Y. Mengesha9,10. in South Africa the mean age of the subjects was $53.8 \pm 12.2$ years.

Sex-Wise Distribution of the Cases and Controls 
In this study, $50 \%$ of the study group were males and $50 \%$ of the study group were females. The males and females were almost equally distributed with a male:female ratio of 1:1.

\section{Duration of Diabetes among the Study Group}

In this study, $31 \%$ of the cases were newly detected type 2 diabetes mellitus. The duration of diabetes in $29 \%$ of cases was between 1-5 years and only $7 \%$ of cases had diabetes for more than 15 years. In the control group, none of the patients had diabetes. The average duration of diabetes among the cases was $5.69 \pm 6.43$ years. In a similar study done by SV Madhu et al, the average duration of diabetes among diabetics was $2.32 \pm 3.03$ years.

\section{Duration of Diabetes and the Presence of Dyslipidaemia among the Cases}

In this study, $87 \%$ of cases had dyslipidaemia irrespective of duration of diabetes. It was found that there is no correlation between duration of diabetes and dyslipidaemia as the $p$ value (0.327) is not significant. Our study is consistent with the study done by SV Madhu et al.

\section{HbA1C Value among the Cases}

In this study, the mean $\mathrm{HbA1C}$ value among the cases was $7.78 \pm 1.60$. In the study group, $70 \%$ of the cases had poor glycaemic control (HbA1C $>7 \%$ ) and only $30 \%$ of cases had good glycaemic control $(\mathrm{HbA} 1 \mathrm{C}<7 \%)$. This association has a $\mathrm{p}$ value of 0.000 , which is statistically significant. In the study done by Addisu Y. Mengesha, ${ }^{11}$ the mean HbA1C was $9.56 \pm 2.6 \%$.

\section{Correlation between HbA1C Value and Dyslipidaemia}

In this study, $60 \%$ of the cases with dyslipidaemia had poor glycaemic control (HbA1C $>7 \%$ ) whereas $27 \%$ of the cases with dyslipidaemia had good glycaemic control ( $\mathrm{HbA1C}<7 \%)$. This association has a p value of 0.738 , which is statistically not significant. Hence, there was no correlation between HbA1c value and dyslipidaemia. This differs from the study done by Haseeb Ahmad Khan in which HbA1C showed direct and significant correlation with TC, TG, LDL, and inverse correlation with HDL.

\section{Prevalence of Hypertension among the Study Group}

In the present study, the prevalence of hypertension among the cases was $44 \%$ and among the controls none of them had hypertension. $(p=0.000)$. In the study done by Sumesh Raj et al, 108 the prevalence of hypertension was seen to be significantly higher in the cases (28\%), which is consistent with our study.

\section{Total Cholesterol Levels among the Cases and Controls}

In this study, in the fasting state, $25 \%$ of cases had total cholesterol levels of $>200 \mathrm{mg} / \mathrm{dL}$ as compared with the controls where $18 \%$ of them had total cholesterol of $>200$ $\mathrm{mg} / \mathrm{dL}$. This association has a $\mathrm{p}$ value of 0.133 , which is statistically not significant. Hence, the pattern of distribution of patients in different cholesterol levels was found to be similar in both the cases and controls.

Similar observations were made in the studies done by SV Madhu et al 12,13. However, in the study done by Sumesh Raj et al, it was found that diabetics had significantly higher levels of TC compared to the controls $(\mathrm{p}<0.05)$.
In this study, the cases had a mean TC level of $169.70 \pm 39.917 \mathrm{mg} / \mathrm{dL}$ in the fasting state and $180.74 \pm 38.76$ $\mathrm{mg} / \mathrm{dL}$ in the postprandial state. The controls had a mean TC level of $168.02 \pm 34.65 \mathrm{mg} / \mathrm{dL}$ in the fasting state and $165.06 \pm 39.27 \mathrm{mg} / \mathrm{dL}$ in the postprandial state. This association has a $\mathrm{p}$ value of 0.854 , which is statistically not significant.

Hence, there was no significant increase in the postprandial TC level in the cases compared to that of the controls.

Similar observations were made in the studies done by SV Madhu et al $^{14} 110$ wherein the cases had a mean TC level of $209.45 \pm 40.27 \mathrm{mg} / \mathrm{dL}$ in the fasting state and peak mean TC level of $232.45 \pm 53.13 \mathrm{mg} / \mathrm{dL}$ in the postprandial state. The controls had a mean TC level of $197.6 \pm 57.13 \mathrm{mg} / \mathrm{dL}$ in the fasting state and peak mean TC level of $210.35 \pm 54.31 \mathrm{mg} / \mathrm{dL}$ in the postprandial state.

\section{LDL-C levels among the Cases and Controls}

In this study, in the fasting state $31 \%$ of cases had LDL-C levels of $<100 \mathrm{mg} / \mathrm{dL}$ whereas $23 \%$ of controls had LDL-C of $<100$ $\mathrm{mg} / \mathrm{dL}$. This association has a $\mathrm{p}$ value of 0.035 , which is statistically significant. Thus, in the fasting state, the cases had a lower LDL-C levels compared to that of the controls.

This does not correlate with the study done by Sumesh Raj et al and SV Madhu et al, which showed that LDL-C was higher in the diabetics than in the controls.

In this study, the diabetics had a mean LDL-C level of $92.3 \pm 27.699 \mathrm{mg} / \mathrm{dL}$ in the fasting state, which is within the normal range. In the strong heart study done by Howard BV et al 15,16 it was shown that in American Indians, LDL cholesterol level was the most significant predictor of increased CHD despite an average LDL cholesterol level of approximately 115 $\mathrm{mg} / \mathrm{dL}$ in diabetics. In this study, LDL was a strong predictor of CHD at levels as low as $70 \mathrm{mg} / \mathrm{dL}$.

In this study, the cases had a mean LDL-C level of $92.3 \pm 27.699 \mathrm{mg} / \mathrm{dL}$ in the fasting state and $100.62 \pm 37.043$ $\mathrm{mg} / \mathrm{dL}$ in the postprandial state. The controls had a mean LDL$\mathrm{C}$ of $165.06 \pm 34.184 \mathrm{mg} / \mathrm{dL}$ in the fasting state and $165.06 \pm 34.184 \mathrm{mg} / \mathrm{dL}$ in the postprandial state. This association has a p value of 0.003 , hence statistically significant.

Thus, in the postprandial state, the cases had a significant decrease in LDL-C level whereas the controls had a marginal increase in LDL-C level compared to that of the fasting state.

This correlates with a study done by Lund et al, which showed that in diabetics, LDL-C decreased significantly postprandially $(\mathrm{p}<0.005)$.

VLDL-C levels among the cases and controls.

In this study, in the fasting state, $37 \%$ of cases had total VLDL-C levels of $>40 \mathrm{mg} / \mathrm{dL}$ as compared with that of the control group whereas only $8 \%$ of the controls had VLDL-C levels of $>40 \mathrm{mg} / \mathrm{dL}$. This association has $\mathrm{p}$ value of 0.000 , which is statistically significant.

Thus, cases with diabetes were found to have elevated VLDL-C levels when compared with that of controls. This correlates with the study done by Angela A. Rivellese et al 17

In this study, the cases had a mean VLDL-C level of $50.39 \pm 63.27 \mathrm{mg} / \mathrm{dL}$ in the fasting state and $34.56 \pm 18.173$ $\mathrm{mg} / \mathrm{dL}$ in the postprandial state. The controls had a mean VLDL-C level of $32 \pm 22.372 \mathrm{mg} / \mathrm{dL}$ in the fasting state and 
$30.2 \pm 15.139 \mathrm{mg} / \mathrm{dL}$ in the postprandial state. This association has a $p$ value of 0.82 , which is statistically not significant.

Hence, there was no significant increase in the postprandial VLDL-C levels in both the cases and controls. This correlates with the study done by Angela A. Rivellese et al 17

\section{Triglyceride levels among the Cases and Controls}

In this study, in the fasting state, $58 \%$ of cases had total TG levels of $>150 \mathrm{mg} / \mathrm{dL}$ as compared with that of control group where $32 \%$ of them had TG levels of $>150 \mathrm{mg} / \mathrm{dL}$. This association has a $\mathrm{p}$ value of 0.000 , which is statistically significant.

Thus, in the fasting state cases with diabetes were found to have elevated triglyceride levels when compared with that of the controls. This correlates with the studies done by Sumesh Raj et al, SV Madhu et al18, and Angela A. Rivellese et al.

In this study, the cases had a mean TG level of $193.48 \pm 109.63 \mathrm{mg} / \mathrm{dL}$ in the fasting state and $235.48 \pm 147.75$ $\mathrm{mg} / \mathrm{dL}$ in the postprandial state. The controls had a mean TG level of $133.06 \pm 59.46 \mathrm{mg} / \mathrm{dL}$ in the fasting state and $142.29 \pm 65.34 \mathrm{mg} / \mathrm{dL}$ in the postprandial state. This association has a $\mathrm{p}$ value of 0.000 . Hence, statistically significant.

Hence, there was a significant increase in the postprandial TG level in the cases compared to that of the controls.

Similar observations were made in the studies done by SV Madhu et al 18 wherein the cases had a mean TG level of $187.1 \pm 63.45 \mathrm{mg} / \mathrm{dL}$ in the fasting state and peak mean TG level of $425.2 \pm 204.47 \mathrm{mg} / \mathrm{dL}$ in the postprandial state. The controls had a mean TG level of $156.85 \pm 76.57 \mathrm{mg} / \mathrm{dL}$ in the fasting state and peak mean TG level of $283.9 \pm 116.94 \mathrm{mg} / \mathrm{dL}$ in the postprandial state. Similar observations were also made in the studies done by Sumesh Raj et al ${ }^{19}(\mathrm{p}<0.01)$ and Angela A. Rivellese et al.

\section{HDL-C levels among the Cases and Controls}

In this study, it was observed that in males $62.3 \%$ of the cases and controls had HDL-C levels of $<35 \mathrm{mg} / \mathrm{dL}$ in the fasting state. Similarly, in females, $80.9 \%$ of the cases and $89.4 \%$ of the controls had HDL-C levels of $<45 \mathrm{mg} / \mathrm{dL}$ in the fasting state. This association has a $\mathrm{p}$ value $>0.05$, which is not significant. Hence, there was no significant difference in the HDL-C levels in both the cases and controls in the fasting state.

This correlates with the study done by Sumesh Raj et al, which showed no significant difference in the HDL-C levels in the diabetics and controls.

This does not correlate with the study done by SV Madhu et al, which showed that diabetics had lower HDL-C levels compared to that of the controls. Though, the mean HDL-C level in diabetics in our study was low $(34.46 \pm 10.92 \mathrm{mg} / \mathrm{dL})$, it was similar to that of the controls. Hence, the controls also had significant dyslipidaemia in our study.

In this study, the cases had a mean HDL-C level of $48.44 \pm 17.721 \mathrm{mg} / \mathrm{dL}$ in the fasting state and $38.761 \pm 9.028$ $\mathrm{mg} / \mathrm{dL}$ in the postprandial state. The controls had a mean HDLC level of $33.72 \pm 11.021 \mathrm{mg} / \mathrm{dL}$ in the fasting state and $33.42 \pm 10.779 \mathrm{mg} / \mathrm{dL}$ in the postprandial state. This association has a p value of 0.020 , which is statistically significant. Hence, there was a significant decrease in the postprandial HDL-C level in the cases compared to that of the controls.
Similar observations were made in the studies done by SV Madhu et al 18 in which the cases had a mean HDL-C level of $35.15 \pm 10.84 \mathrm{mg} / \mathrm{dL}$ in the fasting state and $28.05 \pm 10.94$ $\mathrm{mg} / \mathrm{dL}$ in the postprandial state. The controls had a mean HDLC level of $42.9 \pm 14.11 \mathrm{mg} / \mathrm{dL}$ in the fasting state and $37.15 \pm 13.52 \mathrm{mg} / \mathrm{dL}$ in the postprandial state.

\section{CONCLUSION}

1. It was found that there was a raise in triglyceride levels in the postprandial in the state of diabetes patients when compared to their fasting state.

2. It was found that HDL-C levels were decreased in diabetes patients in both fasting and postprandial state when compared to that of controls.

3. It was found that VLDL-C levels were elevated in the fasting state of diabetes patients.

4. There was significant increase in total cholesterol level in fasting state of diabetes patients.

5. There was significant reduction in the LDL-C levels in fasting state of diabetes patients.

\section{REFERENCES}

1. Havel RJ, Kane JP. Structure and metabolism of plasma lipoproteins. In: Scriver CR, Beaudet AL, Sly WS, ed. The Metabolic and Molecular Bases of Inherited Disease, vol 2. $8^{\text {th }}$ ed. New York: McGraw-Hill 2001:2705-16.

2. Rader DJ, Hobbs. Disorders of lipoprotein metabolism. In: Kasper DL, Braunwald E, Fauci AS, ed. Harrison's Principles of Internal Medicine. 16 $16^{\text {th }}$ ed. New York: McGraw-Hill 2005:2286-98.

3. Brunzell JD, Hazzard WR, Motulsky AG, et al. Evidence for diabetes mellitus and genetic forms of hypertriglyceridemia as independent entities. Metabolism 1975;24(10):1115-21.

4. Abrams JJ, Ginsberg H, Grundy SM. Metabolism of cholesterol and plasma triglycerides in nonketotic diabetes mellitus. Diabetes 1982;31:903-10.

5. Myant NB. Cholesterol Metabolism, LDL, and the LDL Receptor, San Diego, Academic Press, 1990.

6. Cowie CC, Howard BV, Harris MI. Serum lipoproteins in African Americans and whites with non-insulin-dependent diabetes in the US population. Circulation 1994;90(3):1185-93.

7. Howard BV, Cowan LD, Go O, et al. Adverse effects of diabetes on multiple cardiovascular disease risk factors in women. The strong heart study. Diabetes 1998;21(8):1258-65.

8. Zliversmit DB. Atherosclerosis: a postprandial phenomenon. Circulation 1979;60(3):472-85.

9. Patsch JR, Miesenbock G, Hopferwieser T, et al. Relation of triglyceride metabolism and coronary heart disease: studies in postprandial state. Arteriosclerosis and Thromb 1992;12(11):1336-45.

10. Mayes PA, Botham KM. Lipids of physiologic significance. Murray RK, Granner DK, Mayes PA, et al. (Editors). In Harper's Illustrated Biochemistry. 26 ${ }^{\text {th }}$ edn. Mcgraw Hill USA, 2003:121-32.

11. American Diabetes Association. Standards of medical care for patients with diabetes mellitus. Diabetes Care 2000;23(Suppl 1):S57-S60. 
12. Mahley RW, Innerarity TL. Lipoprotein receptors and cholesterol homeostasis. Biochim Biophys Acta 1983;737(2):197-222.

13. Buhman KK, Chen HC, Farese RV. The enzymes of neutral lipid synthesis. J Biol Chem 2001;276:40369-72.

14. Mahley RW, Weisgraber KH, Bersot TP. Disorders of lipid metabolism. Kronenb HM, Melmed S, Polonsky KS, et al. (Editors). In Williams Textbook of Endocrinology. 11 th edition. Saunders Elsevier, Philadelphia 2008:1589-655.

15. Carlson LA, Rosenhamer G. Reduction of mortality in the Stockholm ischaemic heart disease secondary prevention study by combined treatment with clofibrate and nicotinic acid. Acta Med Scand 1988;223(5):405-18.

16. Expert Panel on Detection, Evaluation, and Treatment of High Blood Cholesterol in Adults. Executive summary of the third report of the National Cholesterol Education Program (NCEP) expert panel on detection, evaluation, and treatment of high blood cholesterol in adults (Adult Treatment Panel III). JAMA 2001;285(19):2486-97.
17. Brewer HB. Hypertriglyceridemia: changes in the plasma lipoproteins associated with an increased risk of cardiovascular disease. Am J Cardiol 1999;83(9B):3F-12F.

18. Howard BV, Robbins DC, Sievers ML, et al. LDL cholesterol as a strong predictor of coronary heart disease in diabetic individuals with insulin resistance and low LDL: the strong heart study. Arterioscler Thromb Vasc Biol 2000;20(3):830-5.

19. American Diabetes Association. Management of dyslipidaemia in adults with diabetes. Diabetes Care 2003;26(Suppl 1):S83-6. 